\title{
Effect of grain boundary segregations on martensitic transformation temperatures in NiTi bi-crystals
}

\author{
R.I. Babicheva ${ }^{\dagger, 1}$, A. S. Semenov' ${ }^{2}$, S. V. Dmitriev ${ }^{3,4}$, K. Zhou ${ }^{5}$ \\ †ri.babicheva@gmail.com \\ ${ }^{1}$ Environmental Process Modelling Centre, Nanyang Environment \& Water Research Institute, Nanyang Technological \\ University, 1 Cleantech Loop, CleanTech One, Singapore, 637141, Singapore \\ ${ }^{2}$ Mirny Polytechnic Institute (branch) of the North-Eastern Federal University, 5 Tikhonova St., Mirny, 678174, Russia \\ ${ }^{3}$ Institute for Metals Superplasticity Problems of RAS, 39 Khalturin St., Ufa, 450001, Russia \\ ${ }^{4}$ National Research Tomsk State University, 36 Lenin Av., Tomsk, 634050, Russia \\ ${ }^{5}$ School of Mechanical and Aerospace Engineering, Nanyang Technological University, \\ 50 Nanyang Avenue, Singapore, 639798, Singapore
}

\begin{abstract}
NiTi alloys are very important in a number of applications since they demonstrate shape memory effect, which is due to the martensitic phase transition with the transition temperatures close to the room temperature. Many factors affect transition temperatures of the alloy, including a variation of its chemical composition and thermo-mechanical treatment, which affects grain size, dislocation density, and other crystal structure parameters. It is well-known that the chemical composition of the alloys in grain boundaries can differ significantly from that in the bulk due to segregation of certain elements from the matrix to the grain boundaries. The effect of grain boundary segregations on the martensite transformation temperatures is still poorly understood. In the present molecular dynamics study, the possible effect of segregation of $\mathrm{Ti}$ or $\mathrm{Ni}$ atoms along $\Sigma 25$ tilt grain boundary on the forward and reverse martensitic transformations is analyzed. The segregation is simulated by replacing the monoatomic Ti or Ni layer in the grain boundary with $\mathrm{Ni}$ or Ti layer, respectively. The results are compared to the case of no segregations. We analyze the initial relaxed and thermalized structures of the bi-crystals in austenite state as well as the temperature dependencies of potential energy per atom and volumetric dilatation. It is found that segregations may significantly decrease the start and finish temperatures of the martensitic transformation, and this effect is more pronounced for segregations of $\mathrm{Ni}$.
\end{abstract}

Keywords: shape memory alloy, martensitic phase transformation, grain boundary, segregation, molecular dynamics.

УДК: 538.91

\section{Влияние зернограничных сегрегаций на температуры мартенситного превращения в бикристаллах $\mathrm{NiTi}$}

\author{
Бабичева Р. И. ${ }^{\dagger}, 1$ Семенов А.С. ${ }^{2}$, Дмитриев С. В. ${ }^{3,4}$, Жоу К. ${ }^{5}$ \\ ${ }^{1}$ Environmental Process Modelling Centre, Nanyang Environment \& Water Research Institute, Nanyang Technological \\ University, 1 Cleantech Loop, CleanTech One, Singapore, 637141, Singapore \\ ${ }^{2}$ Мирнинский политехнический институт (филиал) Северо-Восточного федерального университета, \\ ул. Тихонова, 5, Мирный, 678174, Россия \\ ${ }^{3}$ Институт проблем сверхпластичности металлов РАН, ул. Халтурина, 39, Уфа, 450001, Россия \\ ${ }^{4}$ Национальный исследовательский Томский государственный университет, пр. Ленина, 36, Томск, 634050, Россия \\ ${ }^{5}$ School of Mechanical and Aerospace Engineering, Nanyang Technological University,
} 50 Nanyang Avenue, Singapore 639798, Singapore

Сплавы NiTi находят разнообразные применения, поскольку они демонстрируют эффект памяти формы, который обусловлен мартенситным фазовым переходом, с температурами перехода, близкими к комнатной температуре. На температуру перехода сплава влияют многие факторы, в том числе, его химический состав и термомеханическая обработка, которая влияет на размер зерна, плотность дислокаций и другие параметры кристаллической структуры. Хорошо известно, что химический состав сплавов в границах зерен может значительно отличаться от химического составав объемекристаллитов из-засегрегации определенныхэлементов пограницамзерен. Влияниезернограничных сегрегаций на температуры мартенситных превращений до сих пор недостаточно изучено. В настоящем исследовании, 
методом молекулярной динамики анализируется возможное влияние сегрегации атомов Ті или Ni вдоль границы зерен наклона $\Sigma 25$ на температуры прямых и обратных мартенситных превращений. Сегрегация вводится путем замены одного атомного слоя Ті или $\mathrm{Ni}$ на границе зерна на слой $\mathrm{Ni}$ или Ti, соответственно. Результаты сравниваются со случаем отсутствия зернограничных сегрегации. Анализируются исходные релаксированные и термализованные структуры бикристаллов в аустенитном состоянии, а также температурные зависимости потенциальной энергии на атом и объемной дилатации. Обнаружено, что сегрегации может значительно понижать начальную и конечную температуры мартенситного превращения, и этот эффект более выражен для сегрегаций Ni.

Ключевые слова: сплав с памятью формы, мартенситное фазовое превращение, граница зерна, сегрегация, молекулярная динамика.

\section{Introduction}

Unique functional properties of NiTi based shape memory alloys (SMA) associated with shape memory effect and superelasticity, realizing through martensitic phase transformation (MT), as well as very good mechanical properties and high corrosion resistance make them suitable for numerous applications [1-5].

It is well-established that grain boundaries (GBs) in metals and alloys offer favourable sites for segregation of particular impurities. The concept which implies control, design and optimisation of GB network for improving properties of materials through chemical composition and structural manipulation of GBs via solute decoration, called Grain Boundary Segregation Engineering [6,7], is becoming popular. A great effort involving experimental studies was made so far for fundamental understanding of the phenomenon of GB segregations. It was established that GB can be characterized by the type of phases at interphase. Dillon et al. [8] have identified six different GB phases (also called "complexions") that were validated by high-resolution electron microscopy. They include the intrinsic or clean GB, sub-monolayer, bi-layer, multi-layer, an equilibrium thickness amorphous intergranular film, and a complete GB wetting film, and it was revealed that at certain conditions, such complexions can transform from one type to another $[9,10]$. These complexions and transitions between them can change diffusivity of atoms in GBs [11-13] and strongly influence properties of materials in general $[14,15]$. Complexion mediated MT in titanium has been thoroughly analyzed by Zhang et al. [16]. GBs possess the excess free volume, which promotes an atomic reordering that is necessary for the dislocation emission process [17]. Recently, authors of [18] reported that $\mathrm{Zr}$ segregation to GBs and formation of amorphous complexion promote dislocation emission, and at the same time can facilitate the dislocation pinning at GBs, while Borovikov et al. [19] showed that solute addition to GBs can suppress dislocation emission. Due to the ability to accommodate dislocation emission and adsorption, such intergranular films in GBs can strengthen materials [20-25] and improve the structural thermal stability of nanocrystalline alloys [26], and they could be an alternative method to thermo-mechanical training upon material cycling [27]. On the contrary, there are works demonstrating that some complexions in GBs can cause severe embrittlement [28-31]. Recently, it was demonstrated that $\mathrm{Ni}$ and $\mathrm{W}$ atoms can form the amorphous $\mathrm{GB}$ complexions in NiTi alloys that contribute to the high stability of nanocrystalline structure [32], that was explained by the decrease of GB energy by $\mathrm{Ni}$ segregation. The presence of $\mathrm{Ti}$ atoms was observed in GBs of NiTi alloy subject to the radiotracer technique with
${ }^{44} \mathrm{Ti}$ and ${ }^{63} \mathrm{Ni}$ radioisotopes [13]. It was shown that at relatively high $\mathrm{Cu}$ content, the $\mathrm{GB}$ segregation of $\mathrm{Cu}$ can also be observed in NiTi-based SMAs [34]. By means of first-principle modelling, the peculiarities of $\mathrm{Mg}$ and $\mathrm{Zn}$ segregations in $\Sigma 5$ tilt GB in aluminum has been analyzed [34]. According to the results obtained in [35], some of the symmetric $\Sigma 3$ and $\Sigma 9$ tilt grain boundaries retarded MT, while others promote MT in NiTi alloy.

Nucleation of new martensite domains can be either hindered or promoted by properly oriented elastic strains in the crystal. Inhomogeneities in elastic strain can produce local regions where nucleation of new phase is promoted and martensite plates are oriented during transformation. For instance, dislocations can be considered as the nucleation centres for martensite domains, increasing the temperature of the direct martensitic transformation in comparison with the homogeneous martensitic transformation [36,37]. Using classical molecular dynamics simulations, the phase transition in NiTi with B2/B19' interphase was studied [38]. According to this work, the phase boundary with misfit dislocations produces inhomogeneous elastic strains that provide sites for heterogeneous B2 phase nucleation.

It can be expected that GB segregations in NiTi SMAs can severely affect phase transformation characteristics. However, there are quite a few works devoted to this subject. The complexity of NiTi based SMAs brings a significant challenge for comprehensive understanding of these alloys, and it requires involving not only experimental methods, but also computational simulations. Therefore, the current work aims to study the effect of $\mathrm{Ni}$ and Ti segregations to $\Sigma 25$ tilt GBs of NiTi bi-crystals on MT characteristic temperatures by means of the molecular dynamics simulations. This paper can be regarded as a continuation of our previous work devoted to NiTi bi-crystals having tilt or twist GBs without segregations [39], and therefore it will be focused on the effect of GB segregations of Ni and Ti on MT temperatures in comparison with our previous results.

\section{Modeling}

Ni-50\%Ti SMA without GB segregation and binary NiTibased alloys with GB segregations of Ti or $\mathrm{Ni}$ atoms are studied in this work. In the austenite state, at high temperature, $\mathrm{NiTi}$ SMAs have B2 superstructure based on the bcc crystal lattice, while at low temperatures, they normally transform to the martensitic B19' phase with monoclinic lattice.

$\mathrm{MD}$ simulation of the equiatomic alloy without GB segregation is conducted for a computational cell in the form of rectangular parallelepiped that was used in our previous work [39]. $\mathrm{Ni}$ and $\mathrm{Ti}$ atoms of the rectangular cell 
$\left(12.8 \times 4.0 \times 12.8 \mathrm{~nm}^{3}\right)$ form two B2 crystals separated by the symmetric $\Sigma 25$ (710) tilt GBs with the $<010>$ misorientation axis (Fig. 1a, left image) that is constructed according to the coincidence site lattice model (Fig. 1b). Along with this computational cell, the two cells having GB segregation of $\mathrm{Ti}$ or Ni atoms are constructed from the initial model (Fig. 1a, middle and right images). The periodic boundary conditions are applied along the $x, y$ and $z$-axes. Due to the periodic boundary conditions applied, the multi-layered model is constructed by stacking misoriented single-crystal slabs extended along the $x y$-plane. The size of the computational cell along the $x$-axis is such that no defects appear on the faces of the computational cell parallel to the $y z$-plane. We also do not have any defects on the faces parallel to the $x z$-plane since the size of the cell along $y$-axis includes exactly 12 translational cells of the B2 superstructure. Thus, there are only GBs with the only orientation and having the $x y \mathrm{~GB}$ plane. Even though the layered system was studied here (and many other authors have been working with similar simulation setup), it is referred to as "bi-crystal" because in the computational cell there are two grains separated by two GBs, one GB is in the middle of the cell and another one appears at the top and bottom faces of the cell parallel to the $x y$-plane. In order to introduce GB segregation into the cell, one $\mathrm{Ti}$ or $\mathrm{Ni}$ atomic layer parallel to the $x y$-plane and adjacent to the grains' interfaces is substituted with the $\mathrm{Ni}$ or Ti atoms, respectively. This is done identically for both GBs in the computational cell.

After such procedure, the initial concentration was changed to $\mathrm{Ni}-46.8$ at.\%Ti and $\mathrm{Ni}-53.2$ at.\%Ti for the alloys with $\mathrm{GB}$ segregation of $\mathrm{Ni}$ and $\mathrm{Ti}$, respectively. Hereinafter, the corresponding simulation models of the bi-crystals will be referred to as no_GBS, GBS_Ni, or GBS_Ti, respectively.

Thus, thesegregatedatomsareplacedinGBsbyareplacement of a monatomic layer of $\mathrm{Ni}$ or $\mathrm{Ti}$ by $\mathrm{Ti}$ or $\mathrm{Ni}$, respectively. Let us discuss our choice of th is particular distribution of the segregated atoms: (i) We use the simplest possible way of placing the segregated atoms into GBs which makes it easy to reproduce our results. (ii) Since our study is the first ever MD study of the effect of GB segregations on cyclic martensite transformation in $\mathrm{NiTi}$, this simplest choice looks reasonable. (iii) Placing all segregated atoms in GBs we obtain an extreme situation where one can expect the effect of segregations to appear in the clearest and most pronounced fashion.

MD simulations are performed using the atomic/molecular massively parallel simulator (LAMMPS) program package [40]. Atomic interactions in the alloys are described by the second nearest neighbour modified embedded-atom method potential developed by Ko et al. [41]. This interatomic potential can quite accurately predict and reproduce structural changes during temperatureand stress-induced MT in NiTi SMA alloys [42-44].

It is believed that, along with the rhombohedral $\mathrm{R}$ or orthorhombic B19 intermediate phases (IPs), there are other IPs that can be observed during MT [45]. In this study, forward MT (FMT) is associated with the formation of the B19' martensite phase on cooling either directly from the austenite phase $\left(\mathrm{B} 2 \rightarrow \mathrm{B} 19^{\prime}\right)$, or from IP (IP $\rightarrow$ B19'), or from mixture of B2 and IP, and by analogy, the generation of B2 phase from B19' and/or IP during heating is attributed to the reverse MT (RMT).

Initially, the bi-crystals are relaxed to obtain the structures with a local potential energy minimum. Then, the alloys in the austenite state are subjected to cooling from $450 \mathrm{~K}$ to the temperatures, when the materials are in the B19' state. Subsequent RMT is initiated by heating up the bi-crystals to temperatures when materials are in B2 state. Before such thermal treatment, the bi-crystals are equilibrated for $10 \mathrm{ps}$ at $450 \mathrm{~K}$.

In order to reproduce the MT process more accurately during the simulation, that is especially important taking into account the computational time limitation, temperature is changed by $10 \mathrm{~K}$ steps followed by the structure equilibration at corresponding constant temperature within $50 \mathrm{ps}$ in the NPT ensemble and with the normal stress components kept to be zero and controlled independently. The obtained results, in particular, potential energy and volumetric dilatation of the bi-crystals, are averaged over ten different thermalization times (by $10 \mathrm{fs}$ ).

For atomic structure visualization and differentiation of phases, the so-called adaptive common neighbour analysis (CNA) [46] is applied using the OVITO software $[47,48]$. The CNA method is quite popular for identification of
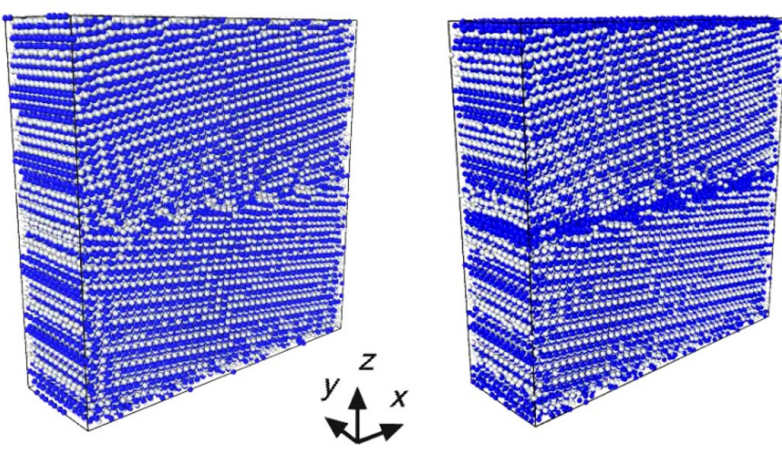

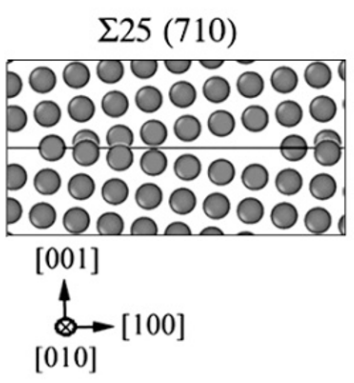

b

Fig. 1. (Color online) Computational cells for NiTi bi-crystal without (on the left) and with GB segregation (on the right) after relaxation (a). Here, only the cell with GB segregation of $\mathrm{Ni}$ is shown. Atoms of $\mathrm{Ti}$ (Ni) are shown in gray (blue). Two GBs of each cell are parallel to the $x y$-plane; one GB is located in the middle, while another one is formed by the bottom and top faces of the cell. Similar segregations are introduced into both GBs. No crystal lattice defects are on the faces of the computational cell parallel to the $x z$-and $y z$-planes. The symmetric $\sum 25(710)<010>$ tilt GB model in bcc structure, shown for one atom type in the B2 supercell (b). 
B2 phase in NiTi alloys [42]. However, it should be noted that this algorithm was not developed for analyzing the monoclinic structure, and therefore it cannot accurately differentiate the B19' phase and IPs. For this, CNA should be utilized together with other methods allowing tracking the MT process, for example, by analyzing temperature dependence of material physical properties.

\section{Results}

The transformation temperatures can be easily determined based on temperature dependences of heat flow and relative change in volume. It is well-known that in crystalline materials, including SMAs, FMT is associated with the heat absorption, while at RMT, material releases the heat. In the current study, during simulation in the NVT ensemble, the abrupt change of system temperature upon MT cannot be observed. However, the MT phenomenon can be tracked via the abrupt change in the system's potential energy, because the latter does not convert to the heat flow upon the transition. Similarly, the abrupt jump attributed to the change of sample volume during cooling and heating through MT must indicate the MT process. During FMT and RMT, NiTi alloys undergo slight decrease and increase in volume, respectively.

Fig. 2 a shows dependences of the potential energy per atom, $E_{p}$, and relative change in volume, $\delta$, for the considered bi-crystals on temperature during cooling down to FMT with the formation of monoclinic B19' phase and subsequent heating up to RMT with the austenite B2 phase formation. In general, it is clearly seen that within the considered temperature interval, the ene rgy of the systems with GB segregation is higher than for the bi-crystal without GB segregation, and this energy shift is more pronounced for segregation of $\mathrm{Ni}$. The material having GB segregation of $\mathrm{Ni}$ has the hysteresis loop associated with the MT much narrower and at lower temperatures as compared to the alloy having the equiatomic composition and that with GB segregation of Ti. For the GBS_Ni case, the change of energy associated with the phase transitions is $\sim 3-5$ times lower. This is due to the fact that GBS_Ni material does not transform to martensite completely at $T=10 \mathrm{~K}$, the lowest studied temperature.

In Fig. $2 \mathrm{~b}$, the corresponding temperature dependences are shown for the change of material volume. Due to significant supercooling of the bi-crystals with GB segregation, especially with $\mathrm{Ni}$ atoms in GBs, the change of volume during MT for the samples are different: $\delta$ for the equiatomic material equals to $\approx 0.03 \%$ that is consistent with literature [49], while that for structures with GBS of $\mathrm{Ti}$ and $\mathrm{Ni}$ is $\approx 0.04 \%$ and $\approx 0.06 \%$, respectively. In fact, for GBS_Ni, the expected value of dilatation is $\approx 0.08 \%$, but it is not reached due to the incomplete MT, as it was already mentioned.

The obtained results indicate that GB segregation of Ni severely inhibits MT, while for the GB segregation of Ti, the MT inhibition is not so pronounced. As can be seen from the graphs plotted in Fig. 2, the martensite transformation start $\left(M_{s}\right)$ and austenite transformation start $\left(A_{s}\right)$ temperatures during FMT and RMT, respectively, can be more easily defined from the volume change curves. For the equiatomic bi-crystal without GB segregation, $M_{s}$ and $A_{s}$ are $290 \mathrm{~K}$ and $400 \mathrm{~K}$, respectively. The corresponding temperatures for the samples with GB segregation of Ti atoms are $200 \mathrm{~K}$ and $320 \mathrm{~K}$, while for the bi-crystal with $\mathrm{Ni}$ atoms in GBs, $M_{s}$ and $A_{s}$ are only $20 \mathrm{~K}$ and $150 \mathrm{~K}$. Roughly, the martensite finish $\left(M_{f}\right)$ and austenite finish $\left(A_{f}\right)$ temperatures can be assessed as $280 \mathrm{~K}$ and $420 \mathrm{~K}, 180 \mathrm{~K}$ and $370 \mathrm{~K}, 10 \mathrm{~K}$ and $170 \mathrm{~K}$ for the equiatomic sample, for material with GB segregation of Ti and for the alloy having extra Ni content in GBs, respectively.

\section{Discussion and summary}

The revealed significant difference in the phase transition temperatures for the studied bi-crystals with GB segregation compared to their counterpart without inclusions in GBs can be attributed to the inhibiting of MT by GB segregation. Fig. 3 shows atomic structure (the $y$ direction view) for the bi-crystals in the initials B2 state, namely after relaxation and subsequent thermalization at $450 \mathrm{~K}$. These slices have two atomic layers, and for analyzing local elastic distortions in a crystal lattice, the atoms are color-coded according to their volumetric elastic strain (from -0.01 (darkest) to 0.03 (lightest)) using the approach described in [50]. In order to differentiate the atomic species, in the top images, Ti is shown by smaller dots than $\mathrm{Ni}$, while in the bottom images the same is shown with the reversed size of dots.

It is seen that the GB structure of the considered materials differs significantly, in particular, for the bi-crystals without

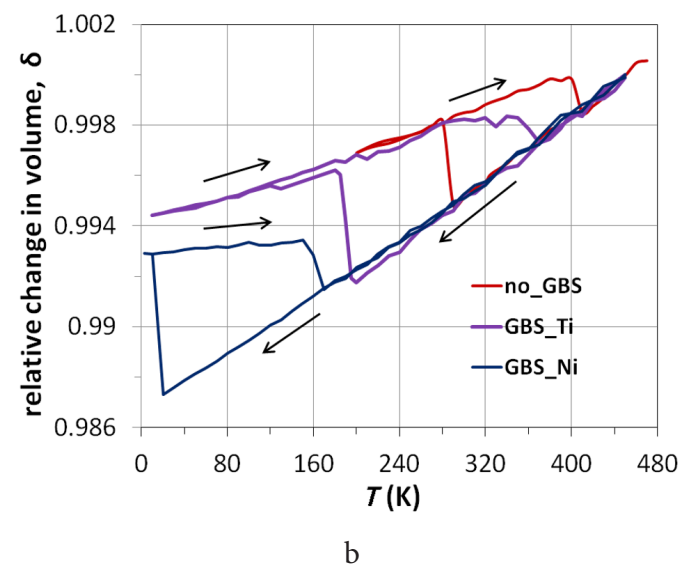

Fig. 2. (Colour online) Potential energy per atom (a) and relative change in volume (b) versus temperature for the considered three bi-crystals. Arrows show the direction of temperature change. 

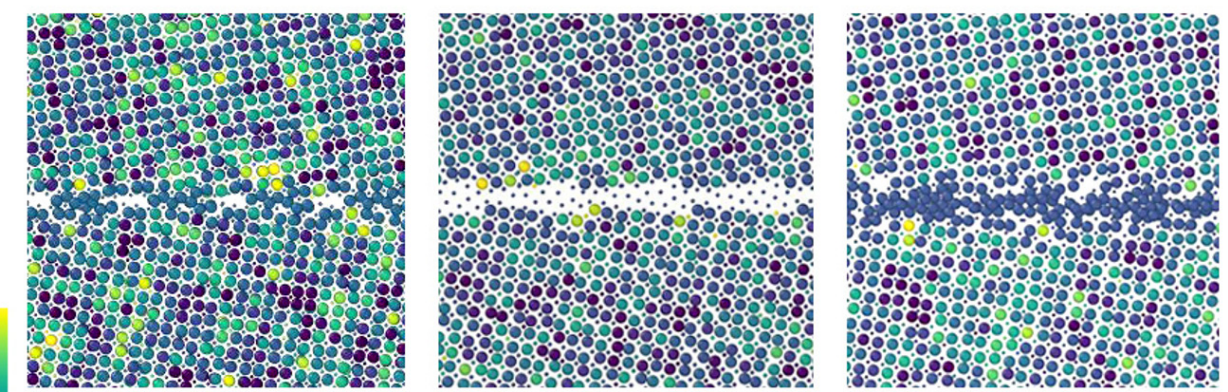

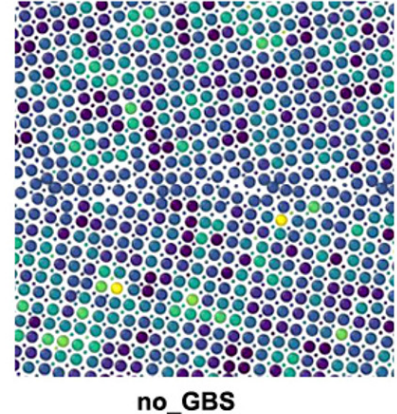

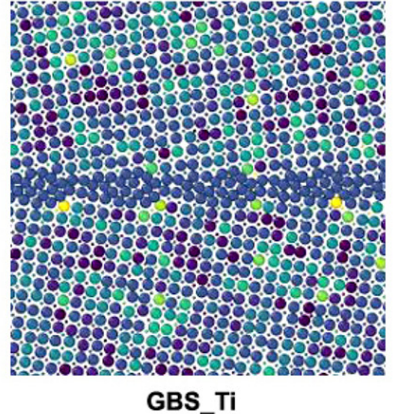

b

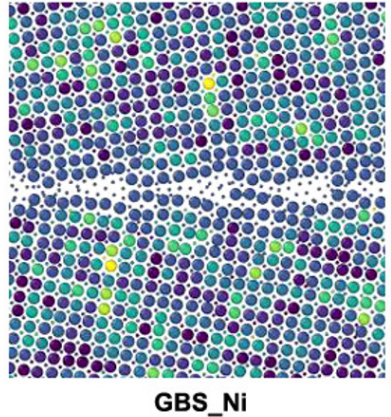

Fig. 3. (Color online) Atomic structure colored according to the volumetric elastic strain (from - 0.01 (darkest) to 0.03 (lightest)) for the bi-crystals without GB segregation (a), with GB segregation of $\mathrm{Ti}(\mathrm{b})$ and with GB segregation of $\mathrm{Ni}(\mathrm{c})$ in the initial state after thermalization at $450 \mathrm{~K}$ (the $y$-axis view). In the top row $\mathrm{Ni}(\mathrm{Ti}$ ) atoms are shown by large (small) dots, while in the bottom row the size of dots is opposite.

GB segregation, the Ti and $\mathrm{Ni}$ atoms in GBs are arranged quite irregularly. In the case of GBS_Ti, the redistribution of Ti atoms creates a thin film complexion in GBs. In GBS_Ni, Ti atoms are close to their lattice positions in B2 superstructure, while $\mathrm{Ni}$ atoms form an amorphous layer. Apparently, the formation of such amorphous layer leads to the suppression of B2-B19' transformation due to the lack of martensite nucleation sites at GBs. Recall that segregated atoms are equally distributed in both GBs (in the middle part and in the bottom/top faces of the cells).

It is useful to note that in the dynamic theory of martensitic transformation [36] the population of $d$-states that are active in the generation of the waves controlling the martensitic transformation significantly depends on the damping of the $s$-electrons $\Gamma_{s}$. It is clear that in the case of an amorphized GB (GBS_Ni), the value of $\Gamma_{s}$ must be obviously greater than in the case of a crystalline film (GBS_Ti). Therefore, the decrease in the $M_{s}$ temperature should be greater for grains with an amorphous GB.

It has been shown that particular atomic arrangements of atoms in GBs indeed can affect the local stress concentrations and change the triggering of phase transitions. For example, authors of [51] reported that particles at GBs of binary SMAs can accommodate transformation strain in adjacent austenite grains, relieving local stress concentration and can enhance local strain compatibility, lowering the critical stress for phase transformation. Multilayer structure characterized by different chemical composition of the layers can hinder MT [52]. It was deduced that segregation of Fe in GBs results in a remarkable decrease of the A2/B2 transition temperature as compared to that in the bulk of B2 FeCo alloy [53]. Thus, segregations can have the opposite effect on the transition temperatures depending on many factors. Obviously, in our case the segregations of $\mathrm{Ti}$, and especially of $\mathrm{Ni}$, strongly hinder MT by relaxing the degree of inhomogeneity in elastic strain distribution near GBs, thus removing the nucleation centres. In the future studies, it would be important to analyze the interaction between dislocations and grain boundaries $[54,55]$.

The obtained results can be concluded as follows.

1. Segregations affect the atomic structure of GBs, in particular, in the case of GBS_Ti, the redistribution of $\mathrm{Ti}$ atoms creates a thin film complexion in GBs. In GBS_Ni, Ti atoms are close to their lattice positions in B2 superstructure, while $\mathrm{Ni}$ atoms form an amorphous layer in GB.

2. Changes in the atomic structure of GBs result in significant reduction of the transition temperatures. This effect is more pronounced for GBS_Ni, since the formation of an amorphous layer in GB leads to the absence of the martensite nucleation sites at GB area resulting in the suppression of the B2-B19' transformation.

3. Numerical results obtained in this study are in a qualitative agreement with the experimental observations $[16-18,51,56]$ and with the theoretical work [36].

Overall, the results of our study suggest that GB segregations can significantly influence characteristics of MT in NiTi SMAs, and therefore it is very important to further investigate their effect in different GB types and at various thermo-mechanical conditions using both computational and experimental approaches.

Acknowledgements. R.I. Babicheva appreciates the financial support provided by the Russian Science Foundation, grant No. 17-79-10410 (molecular dynamics simulations). The work of A.S. Semenov (analysis and discussion of the numerical results) was supported by the Russian Science Foundation, grant No. 18-72-00006. S.V. Dmitriev thanks the Russian Foundation for Basic Research, grant No. 17-02-00984 (design of the research). This work was partly supported by the state assignment of IMSP RAS. 


\section{References}

1. T. Yoneyama, S. Miyazaki. Shape memory alloys for biomedical applications. Woodhead Publishing, Cambridge (2009) $337 \mathrm{p}$.

2. J. Mohd Jani, M. Leary, A. Subic, M.A. Gibson. Mater. Design. 56, 1078 (2014). $\underline{\text { Crossref }}$

3. M.H. Elahinia, M. Hashemi, M. Tabesh, S. B. Bhaduri. Prog. Mater. Sci. 57, 911 (2012). Crossref

4. K. Otsuka, X. Ren. Prog. Mater. Sci. 50, 511 (2005). Crossref

5. L. Sun, W.M. Huang, Z. Ding, Y. Zhao, C.C. Wang, H. Purnawali, C. Tang et al. Mater. Design. 33, 577 (2012). Crossref

6. D. Raabe, S. Sandlöbes, J. Millán, D. Ponge, H. Assadi, M. Herbig, et al. Acta Mater. 61, 6132 (2013). Crossref

7. D. Raabe, M. Herbig, S. Sandlöbes, Y. Li, D. Tytko, M. Kuzmina, D. Ponge, P.-P. Choi. Curr. Opin. Solid St. M. 18, 253 (2014). Crossref

8. S. J. Dillon, M. Tang, W.C. Carter, M.P. Harmer. Acta Mater. 55, 6208 (2007). Crossref

9. C. Hu, J. Luo. Scripta Mater. 158, 11 (2019). Crossref

10. S. Yang, N. Zhou, H. Zheng, S.P. Ong, J.Luo. Phys. Rev. Lett. 120, 085702 (2018). Crossref

11. S. V. Divinski, H. Edelhoff, S. Prokofjev. Phys. Rev. B. 85, 144104 (2012). $\underline{\text { Crossref }}$

12. T. Frolov, S. V. Divinski, M. Asta, Y. Mishin. Phys. Rev. Lett. 110, 255502 (2013). Crossref

13. D. Liu, M. Peterlechner, J. Fiebig et al. Intermetallics. 61, 30 (2015). Crossref

14. P. R. Cantwell, M. Tang, S. J. Dillon, J. Luo, G.S. Rohrer, M. P. Harmer. Acta Mater. 62, 1 (2014). Crossref

15. K. Tai, A. Lawrence, M. P. Harmer, S. J. Dillon. Appl. Phys. Lett. 102, 034101 (2013). Crossref

16. J. Zhang, C.C. Tasan, M. J. Lai, A.-C. Dippel, D. Raabe. Nature Commun. 8, 14210 (2017). Crossref

17. G. J. Tucker, D.L. McDowell. Int. J. Plast. 27, 841 (2011). Crossref

18. V. Turlo, T. J. Rupert. Acta Mater. 151, 100 (2018). Crossref

19. V. Borovikov, M. I. Mendelev, A. H. King. Int. J. Plast. 90, 146 (2017). Crossref

20. Z. Pan, T. J. Rupert. Phys. Rev. B. 93, 134113 (2016). Crossref

21. Z. Pan, T. J. Rupert. Acta Mater. 89, 205 (2015). Crossref

22. R. I. Babicheva, S. V. Dmitriev, D. V. Bachurin, N. Srikanth, Y. Zhang, S. W. Kok, K. Zhou. Int. J. Fatigue. 102, 270 (2017). Crossref

23. A.V. Zinovev, M.G. Bapanina, R.I. Babicheva, N. A.Enikeev, S. V.Dmitriev, K.Zhou. Phys. Met.Metallogr. 118, 65 (2017). Crossref

24. R. I. Babicheva, S. V. Dmitriev, L. Bai, Y. Zhang, S. W. Kok, G. Kang, K. Zhou. Comp. Mater. Sci. 117, 445 (2016). Crossref

25. R.I. Babicheva, S. V. Dmitriev, Y. Zhang, S.W. Kok, K. Zhou. J. Nanomat. 2015, 231848 (2015). Crossref

26. N. Zhou, T. Hu, J. Huang, J. Luo. Scripta Mater. 124, 160 (2016). Crossref

27. R. I. Babicheva, Kh. Ya. Mulyukov. Appl. Phys. A. Mater. 116, 1857 (2014). $\underline{\text { Crossref }}$

28. J. Kang, G. C. Glatzmaier, S.-H. Wei. Phys. Rev. Lett. 111, 055502 (2013). Crossref
29. A. Kundu, K. M. Asl, J. Luo, M. P. Harmer. Scripta Mater. 68, 146 (2013). Crossref

30. J. Luo, H. Cheng, K.M. Asl, C. J. Kiely, M.P. Harmer. Science. 333, 1730 (2011). Crossref

31. L. Feng, R. Hao, J. Lambros, S. J. Dillon. Acta Mater. 142, 121 (2018). Crossref

32. A. Ahadi, A.R. Kalidindi, J. Sakurai, Y. Matsushita, K. Tsuchiya, C.A. Schuh. Acta Mater. 142, 181 (2018). Crossref

33. M. Callisti, B. G. Mellor, T. Polcar. Scripta Mater. 77, 52 (2014). Crossref

34. M.V. Petrik, A.R. Kuznetsov, N.A. Enikeev, Y.N. Gornostyrev, R. Z. Valiev. Phys. Met. Metallogr. 119, 607 (2018). Crossref

35. S.-J. Qin, J.-X. Shang, F.-H. Wang, Y. Chen. Mater. Design. 137, 361 (2018). $\underline{\text { Crossref }}$

36. M.P. Kashchenko, V.G. Chashchina. Phys. Usp. 54, 331 (2011). $\underline{\text { Crossref }}$

37. S. V. Dmitriev, M.P. Kashchenko, J.A. Baimova, R. I. Babicheva, D. V. Gunderov, V.G. Pushin. Letters on Materials. 7, 442 (2017). Crossref

38. S.-J. Qin, J.-X. Shang, X. Wang, F.-H. Wang. Appl. Surf. Sci. 353, 1052 (2015). $\underline{\text { Crossref }}$

39. S. V. Dmitriev, R.I. Babicheva, D.V. Gunderov, V. V. Stolyarov, K. Zhou. Letters on Materials. 8, 225 (2018). Crossref

40. S. Plimpton. J. Comput. Phys. 117, 1 (1995). Crossref

41. W.-S. Ko, B. Grabowski, J. Neugebauer. Phys. Rev. B. 92, 134107 (2015). Crossref

42. W.-S. Ko, S.B. Maisel, B. Grabowski, J.B. Jeon, J. Neugebauer. Acta Mater. 123, 90 (2017). Crossref

43. M. Muralles, S.-D. Park, S. Y. Kim, B. Lee. Comp. Mater. Sci. 130, 138 (2017). Crossref

44. F. Yazdandoost, R. Mirzaeifar. J. Alloy. Compd. 709, 72 (2017). Crossref

45. M.P. Kashchenko, V.G. Chashchina. Materials. Science. Foundations. 81-82, 3 (2015). Crossref

46. J. D. Honeycutt, H. C. Andersen. J. Phys. Chem. 91, 4950 (1987). Crossref

47. A. Stukowski, V. V. Bulatov, A. Arsenlis. Modelling Simul. Mater. Sci. Eng. 20, 085007 (2012). Crossref

48. A. Stukowski. Modelling Simul. Mater. Sci. Eng. 18, 015012 (2010). Crossref

49. Y.C. Shu, K. Bhattacharya. Acta Mater. 46, 5457 (1998). $\underline{\text { Crossref }}$

50. A. Stukowski, A. Arsenlis. Modelling Simul. Mater. Sci. Eng. 20, 035012 (2012). Crossref

51. R. D. Dar, H. Yan, Y. Chen. Scripta Mater. 115, 113 (2016). Crossref

52. H. Wang, X. Yi, Y. Zhu, et al. Mater. Charact. 140, 122 (2018). Crossref

53. Z. S. Tôkei, J. Bernardini, D. L. Beke. Acta Mater. 47, 1371 (1999). Crossref

54. N. B. Burbery, G. Po, R. Das, N. Ghoniem, W. G. Ferguson. Journal of Micromechanics and Molecular Physics. 2, 1750003 (2017). Crossref

55. Q.H. Fang, L.C. Zhang. Journal of Micromechanics and Molecular Physics. 1, 1650008 (2016). $\underline{\text { Crossref }}$

56. R. D. Dar, Y. Chen. Appl. Phys. Lett. 110, 041906 (2017). Crossref 